Jurnal ELTIKOM, Vol. 1 No.1, Juni 2017, Hal 47-55 ISSN 2598-3245 (Print), ISSN 2598-3288 (Online)

Tersedia Online di http://eltikom.poliban.ac.id

\title{
ANALISIS DAN SIMULASI SPEKTRUM SINYAL AM DENGAN MENGGUNAKAN MATLAB
}

\author{
Khairunnisa \\ Politeknik Negeri Banjarmasin \\ e-mail: khairunnisa@poliban.ac.id
}

\begin{abstract}
Amplitude modulation $(A M)$ is merging process of carrier signal with information signal in which the carrier amplitude transmitted is changed following the information signal amplitude. One way to understand the mechanism of the AM signal is understanding the physical characteristics of the AM signal. This is not an easy way because the AM signal involve complex mathematical equations. The software used is the Matlab GUI. The analysis is done by first determining the mathematical equation of AM signal and the component of signal parameters, namely amplitude and frequency. Next, create a design template figure, set the properties of each UIControl component, making the program listing and then analyzed by entering the parameter values of different signal amplitude to produce variation modulation index value $\left(m_{A}\right)$, there are $0.25,0.5,1$ and 1.5. Information frequencies used are $250 \mathrm{~Hz}$ and $500 \mathrm{~Hz}$, and the carrier frequencies are $1.5 \mathrm{kHz}$ and $400 \mathrm{~Hz}$. The results of the analysis show that the limits of the ideal modulation index value $\left(m_{A}\right)$ is: $0 \leq m_{\mathrm{A}} \leq 1$ with the frequency of the carrier signal should be higher than the information signal.
\end{abstract}

Keywords: Amplitude Modulation, Matlab, Signal Spectrum

\begin{abstract}
ABSTRAK
Modulasi amplitudo (Amplitude Modulation / AM) adalah proses penumpangan sinyal pembawa terhadap sinyal informasi dimana amplitudo sinyal pembawa yang dipancarkan berubah mengikuti perubahan amplitudo sinyal informasi. Salah satu cara memahami mekanisme sinyal AM adalah dengan memahami karakteristik fisik sinyal AM. Ini adalah hal yang tidak mudah karena sinyal AM melibatkan persamaan matematika kompleks. Perangkat lunak yang digunakan adalah GUI Matlab. Analisis dilakukan dengan terlebih dahulu menentukan persamaan matematis sinyal AM dan komponen parameter sinyal yaitu amplitudo dan frekuensi. Selanjutnya membuat desain template figure, mengatur properti komponen setiap UIControl, membuat listing programnya untuk kemudian dianalisis dengan memasukkan nilai parameter amplitudo sinyal yang berbeda untuk menghasilkan nilai indeks modulasi $\left(m_{A}\right)$ yang bervariasi yaitu 0.25, 0.5, 1 dan 1.5. Frekuensi informasi sebesar $250 \mathrm{~Hz}$ dan $500 \mathrm{~Hz}$, frekuensi pembawa $1,5 \mathrm{kHz}$ dan $400 \mathrm{~Hz}$. Hasil analisis menunjukkan bahwa batas-batas nilai indeks modulasi $(\mathrm{mA})$ yang ideal adalah $: 0 \leq m_{\mathrm{A}} \leq 1$ dengan frekuensi sinyal pembawa harus lebih tinggi daripada sinyal informasi.
\end{abstract}

Kata Kunci: Matlab, Modulasi Amplitudo, Spektrum Sinyal

\section{PENDAhUluan}

Keperluan akan modulasi mula-mula timbul dalam transmisi radio dari sinyal-sinyal berfrekuensi rendah (misalnya frekuensi audio). Untuk radiasi yang efisien, besar orde dimensi-dimensi antena (ukuran antena) kira-kira harus sama besar dengan orde panjang gelombang (wave-length) dari sinyal yang dipancarkan[3][5].

Kebanyakan sinyal-sinyal informasi berfrekuensi rendah mempunyai frekuensi dalam orde $1 \mathrm{kHz}$. Karena gelombang-gelombang elektromagnetis bergerak dalam ruang angkasa sehingga cepat rambat gelombang sama dengan cepat rambat cahaya yaitu $3.108 \mathrm{~m} / \mathrm{s}$, maka panjang gelombang $(\lambda)$ sinyal yang ditransmisikan adalah sekitar $300 \mathrm{~km}$. Jelas tidak mungkin untuk membuat antena dengan ukuran ini. Masalah ini diatasi dengan menggunakan sinyal frekuensi-rendah tersebut untuk memodulasi sebuah sinyal frekuensi-tinggi yang dinamakan gelombang pembawa (carrier wave),yang kemudian dipancarkan[3][5]. 

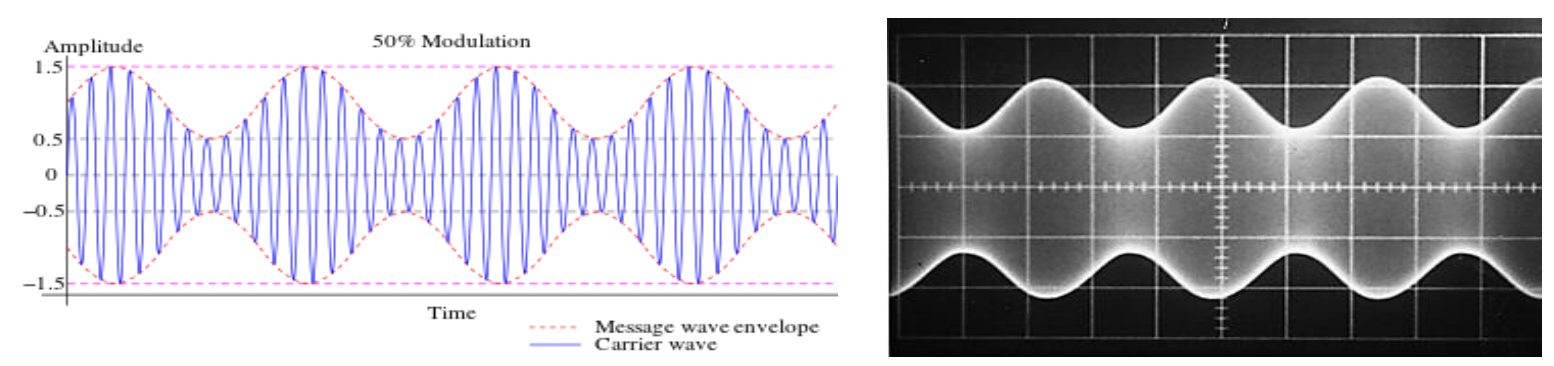

Gambar 1. Karakteristik Sinyal AM

Pemahaman tentang sinyal memerlukan gambaran grafis untuk memahaminya karena sinyal itu sendiri tidak bisa ditangkap oleh panca indra manusia secara fisik. Salah satu cara memahami mekanisme sinyal AM adalah dengan memahami karakteristik fisik sinyal AM. Memahami karakteristik sinyal adalah hal yang tidak gampang, hal ini dikarenakan sinyal AM melibatkan persamaan matematika kompleks.

Karakteristik sinyal AM yang dihasilkan dapat kita gambarkan secara manual dengan mengikuti prosedur penggambaran sketsa grafik yang sudah kita dapatkan dalam pelajaran matematika umum. Tetapi untuk gelombang yang merupakan bentuk penggambaran fungsi kompleks, tentu kita akan mengalami kesulitan dalam sketsanya. Walaupun dengan keuletan yang tinggi, tetap saja akan memakan waktu yang lama. Untuk itu perlu adanya semacam bahasa pemrograman yang mudah dipahami untuk membantu kita dalam menggambar bentuk gelombang yang kita inginkan, salah satu perangkat lunak yang mendukung adalah Matlab.

\section{MetOdOLOGI PENELITIAN}

Langkah-langkah penelitian ditunjukkan pada Gambar 2.
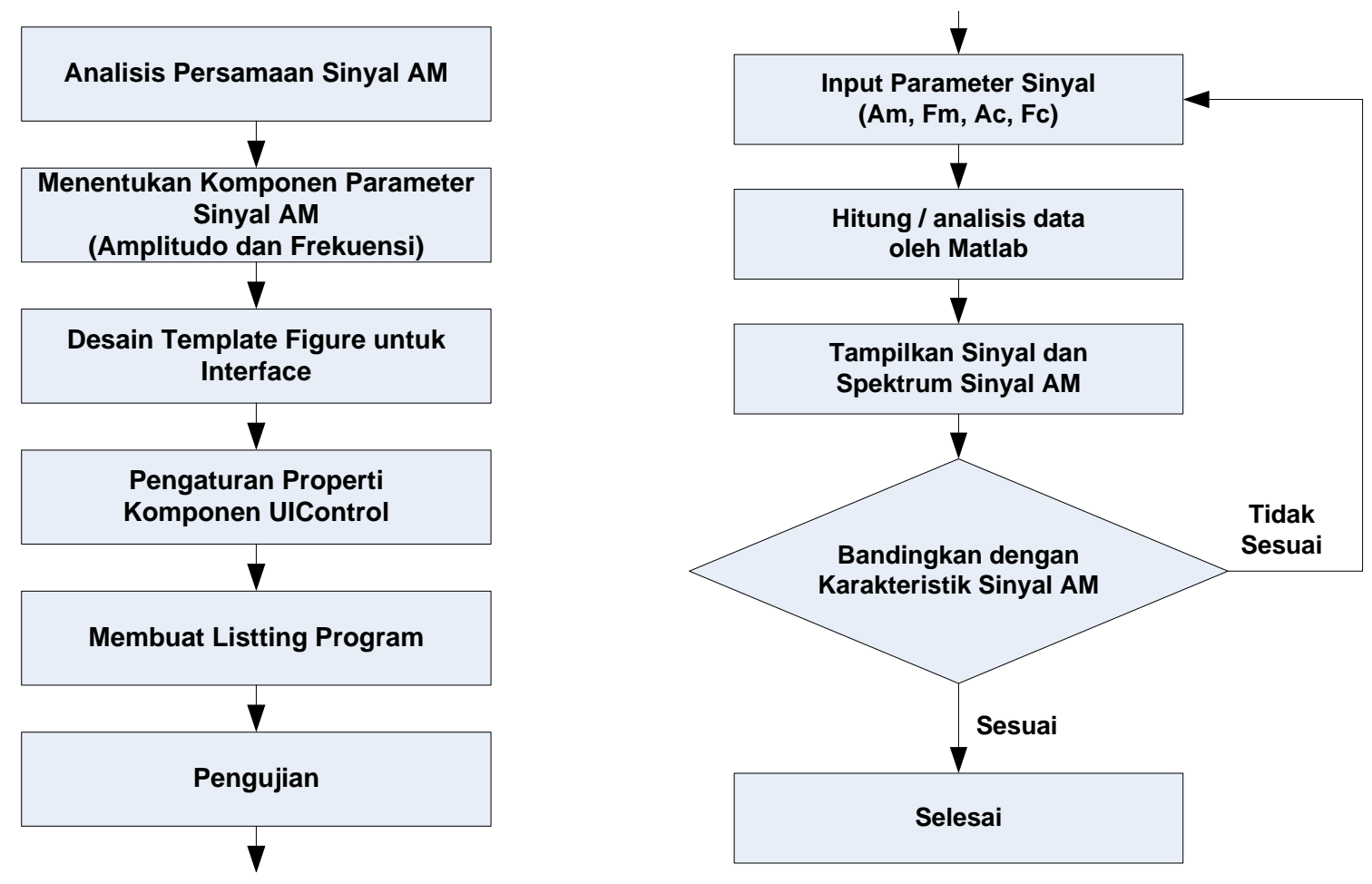

Gambar 2. Flow chart metodologi penelitian yang dilakukan

Analisis dilakukan dengan terlebih dahulu menentukan persamaan matematis sinyal AM dan komponen parameter sinyal yaitu amplitudo dan frekuensi. Selanjutnya membuat desain template figure, mengatur properti komponen setiap UIControl, membuat listing programnya untuk kemudian dianalisis 
dengan memasukkan nilai parameter amplitudo sinyal yang berbeda untuk menghasilkan nilai indeks modulasi ( $\mathrm{mA}$ ) yang bervariasi.

Uji yang dilakukan adalah menjalankan program MATLAB yang sudah dibuat ke dalam sistem, data parameter sinyal diolah untuk membuktikan teori yang dipelajari.hingga dapat menampilkan grafik sinyal. Grafik yang dihasilkan akan dianalisis untuk menentukan nilai parameter yang sesuai dengan karakteristik yang diinginkan.

\section{LITERATUR PUSTAKA}

\section{A. Modulasi Amplitudo (Amplitude Modulation / AM)}

Modulasi amplitudo adalah proses penumpangan sinyal carrier terhadap sinyal informasi dimana amplitudo sinyal carrier berubah sesuai dengan amplitudo sinyal informasi yang dikirimkan[2][3][5][6].

Secara fisis, AM ditunjukkan dalam gambar 3.6 sampai 3.9. Gelombang pembawa yang belum dimodulasikan mempunyai harga amplitudo maksimum yang tetap dan frekuensi yang lebih tinggi daripada sinyal pemodulasi (sinyal informasi), tetapi bila sinyal informasi telah diselipkan, maka harga amplitudo maksimum dari gelombang pembawa akan berubah-ubah sesuai dengan harga-harga sesaat dari sinyal pemodulasi tersebut, dan bentuk gelombang luar atau sampul dari harga-harga amplitudo gelombang yang telah dimodulasi tersebut sama bentuknya dengan gelombang sinyal informasi yang asli $[2][3][5][6]$.

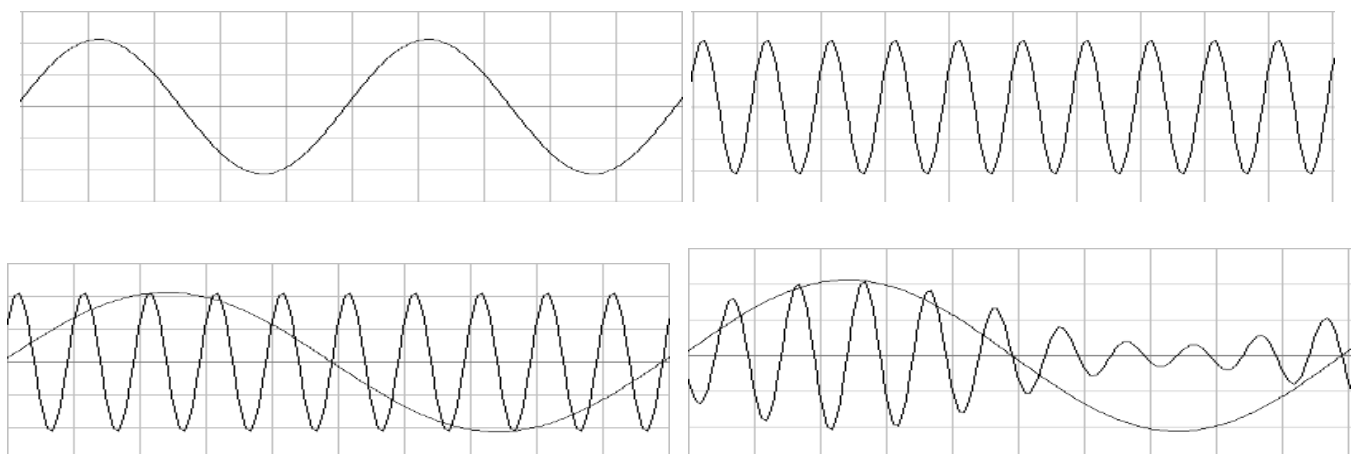

Gambar 3. (atas kiri) sinyal informasi, (atas kanan) sinyal carrier, (bawah kiri) penumpangan sinyal carrier dan sinyal informasi, (bawah kanan) sinyal termodulasi amplitudo

B. Perhitungan Matematis Sinyal AM

Gelombang pembawa selalu berbentuk sinusoida, dan dapat dinyatakan dengan persamaan[3][5]:

$$
\begin{aligned}
x_{C}(t)=A_{C} \sin & \left(\omega_{C} t+\theta\right) \\
x_{C}(\mathrm{t}) & =\text { gelombang pembawa (carrier) } \\
A_{C} & =\text { amplitudo gelombang carrier } \\
\omega_{C} & =2 \pi f_{\mathrm{C}} \\
f_{\mathrm{C}} & =\text { frekuensi gelombang carrier }
\end{aligned}
$$

Sinyal informasi secara matematis direpresentasikan sebagai[3][5]:

$$
\begin{aligned}
x_{M}(t)=A_{M} \sin \omega_{M} t & \\
A_{M} & =\text { sinyal informasi } \\
E_{M \text { maks }} & =\text { amplitudo sinyal informasi } \\
\omega_{M} & =2 \pi f_{\mathrm{M}} \\
f_{\mathrm{M}} & =\text { frekuensi sinyal informasi }
\end{aligned}
$$

Bila suatu sinyal carrier dimodulasi amplitudo, maka amplitudo bentuk gelombang tegangan pembawa dibuat berubah sebanding dengan tegangan sinyal informasi yang memodulasi, sehingga[3][5]:

$$
x_{C}(t)=\left(A_{C}+x_{M}(t)\right) \sin \omega_{C} t
$$

Persamaan (3), adalah persamaan sinyal termodulasi dan dapat ditulis kembali sebagai[3][5]:

$$
x_{A M}(t)=\left(A_{C}+x_{M}(t)\right) \sin \omega_{C} t
$$

$x_{\text {env }}(t)$ pada persamaan (3), adalah persamaan sinyal sampul (envelope)[3][5]: 


$$
x_{\text {env }}(t)=A_{C}+x_{M}(t)
$$

Selanjutnya,

$$
\begin{aligned}
& x_{A M}(t)=\left(A_{C}+A_{M} \sin \omega_{M} t\right) \sin \omega_{C} t \\
& x_{A M}(t)=A_{C}\left(1+\frac{A_{M}}{A_{C}} \sin \omega_{M} t\right) \sin \omega_{C} t
\end{aligned}
$$

Jika indeks modulasi amplitudo didefinisikan sebagai : $m_{A}=\frac{A_{M}}{A_{C}}$

Persamaan (4) dapat ditulis kembali sebagai[3][5]:

$$
x_{A M}(t)=A_{C}\left(1+m_{A} \cdot \sin \omega_{M} t\right) \sin \omega_{C} t
$$

Persamaan (5) diberikan sketsanya dalam gambar 4 untuk berbagai nilai $m_{\mathrm{A}}$ yang berbeda[3][5].
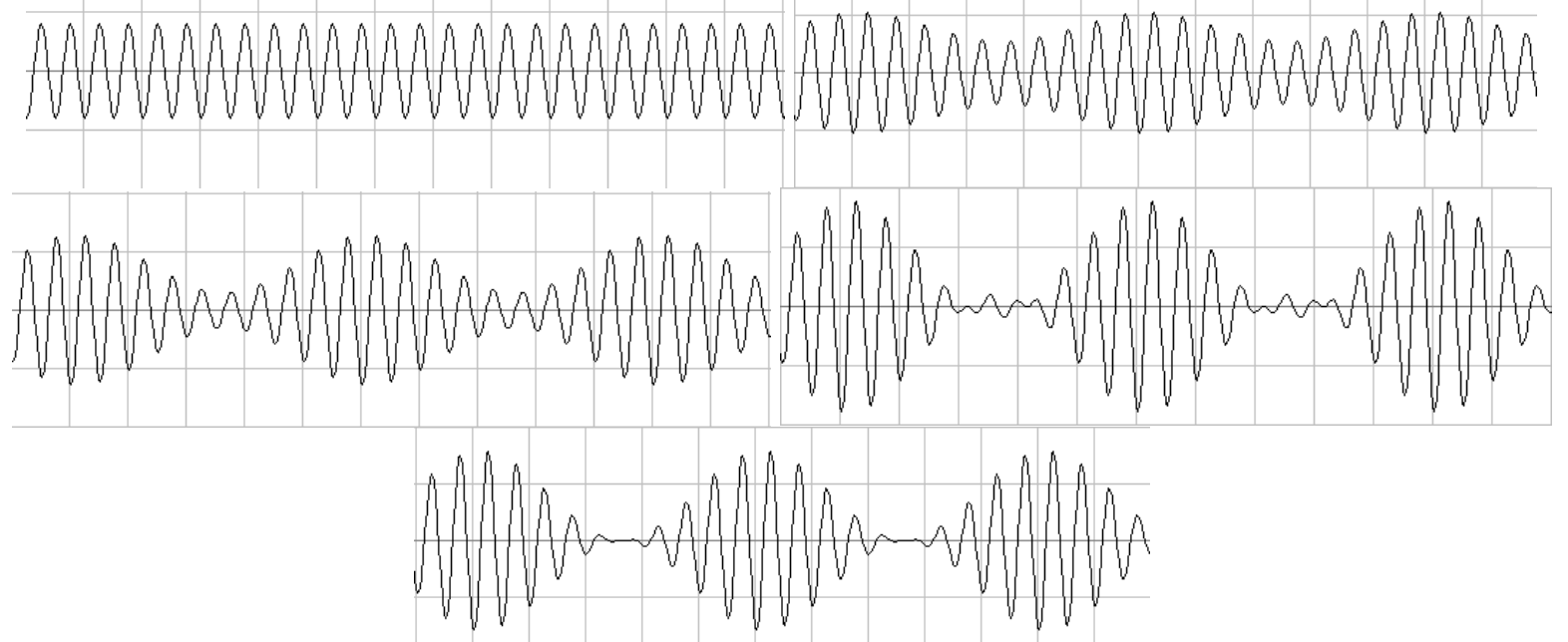

Gambar 4. Bentuk sinyal keluaran gelombang termodulasi untuk indeks modulasi

(atas kiri) $\mathrm{mA}=0$; (atas kanan) $\mathrm{mA}=0,25$; (tengah kiri) $\mathrm{mA}=0,5$; (tengah kanan) $\mathrm{mA}=1$; (bawah) $\mathrm{mA}>1$

Untuk $m_{\mathrm{A}}>1$, sinyal carrier hilang sama sekali dan puncak-puncak dalam dari selubung terpotong. Keadaan ini harus dicegah, karena akan menimbulkan cacat pada sinyal modulasi. Batas-batas nilai $m_{\mathrm{A}}$ dengan mudah dapat dinyatakan sebagai : $0 \leq m_{\mathrm{A}} \leq 1$ [3][5].

Dengan menggunakan identitas trigonometri : $\sin A \sin B=\frac{1}{2}[\cos (A-B)-\cos (A+B)]$, persamaan (5), dapat terus dijabarkan[3][5]:

$$
\begin{aligned}
& x_{A M}(t)=A_{C}\left(1+m_{A} \cdot \sin \omega_{M} t\right) \sin \omega_{C} t \\
& x_{A M}(t)=A_{C}\left(\sin \omega_{C} t+m_{A} \cdot \sin \omega_{C} t \cdot \sin \omega_{M} t\right) \\
& x_{A M}(t)=A_{C}\left[\sin \omega_{C} t+\frac{m_{A}}{2} \cdot\left[\cos \left(\omega_{C} t-\sin \omega_{M} t\right)-\cos \left(\omega_{C} t+\sin \omega_{M} t\right)\right]\right]
\end{aligned}
$$

Persamaan (6) dinyatakan dalam tiga komponen frekuensi[3][5]:

1) $\omega_{C} t-\omega_{M} t$, dengan nilai frekuensi $\left(f_{\mathrm{C}}-f_{\mathrm{M}}\right)$, merupakan frekuensi sisi bawah (Lower Side Band atau LSB)

2) $\omega_{C} t$, dengan nilai frekuensi $f_{\mathrm{C}}$, merupakan frekuensi sinyal carrier

3) $\omega_{C} t+\omega_{M} t$, dengan nilai frekuensi $\left(f_{\mathrm{C}}+f_{\mathrm{M}}\right)$, merupakan frekuensi sisi atas (Upper Side Band atau USB)

Jika asumsi amplitudo $A_{C}=1$ dan $A_{M}=1$, sehingga $m_{A}=1$, maka sinyal dimodulasi penuh, dan spektrum frekuensi ditunjukkan dalam gambar 5 . 


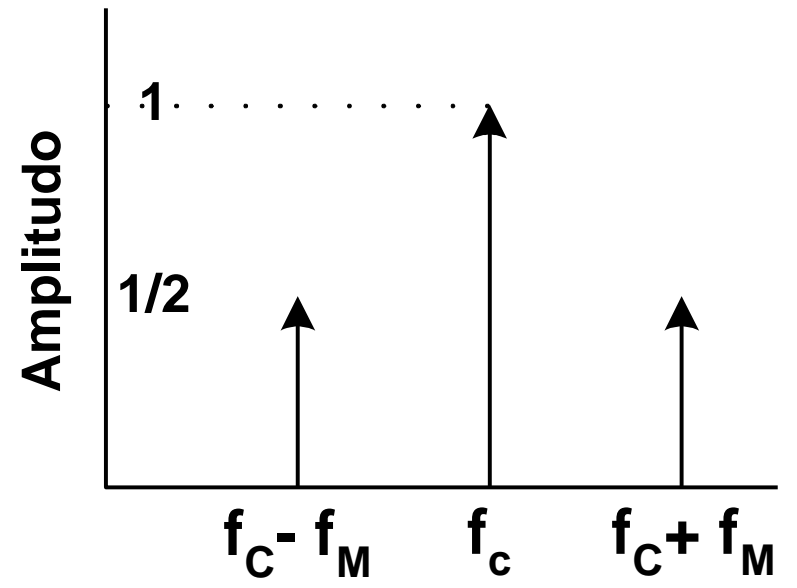

Gambar 5. Spektrum gelombang yang dimodulasi 100\% (penuh)

Bentuk spektrum gelombang seperti yang diperlihatkan pada gambar 5 inilah yang dimaksud dengan AM Double Side Band (AM-DSB) atau sinyal pita ganda dimana pada batasan frekuensi $f_{\mathrm{C}} \leq f \leq f_{\mathrm{C}}+f_{\mathrm{M}}$ disebut sebagai USB dan batasan frekuensi $f_{\mathrm{C}}-f_{\mathrm{M}} \leq f \leq f_{\mathrm{C}}$ disebut sebagai LSB. Masing-masing side band telah berisi informasi lengkap dari sinyal informasi. Oleh sebab itu dimungkinkan untuk mentransmisikan salah satu dari side[3][5].

\section{HASIL DAN PEMBAHASAN}

\section{A. Desain Template}

Desain template dilakukan dengan mengatur posisi setiap komponen UIControl yang dibutuhkan pada halaman layout editor, yaitu Static Text, Button Group, Edit Text,Push Button dan Axes (Gambar 6)[1][4].

B. Mengatur Property Komponen

Property setiap komponen UIControl diatur pada bagian Property Inspector sesuai dengan tabel I. Tampilan figure seperti yang ditunjukkan pada gambar 7[1][4].

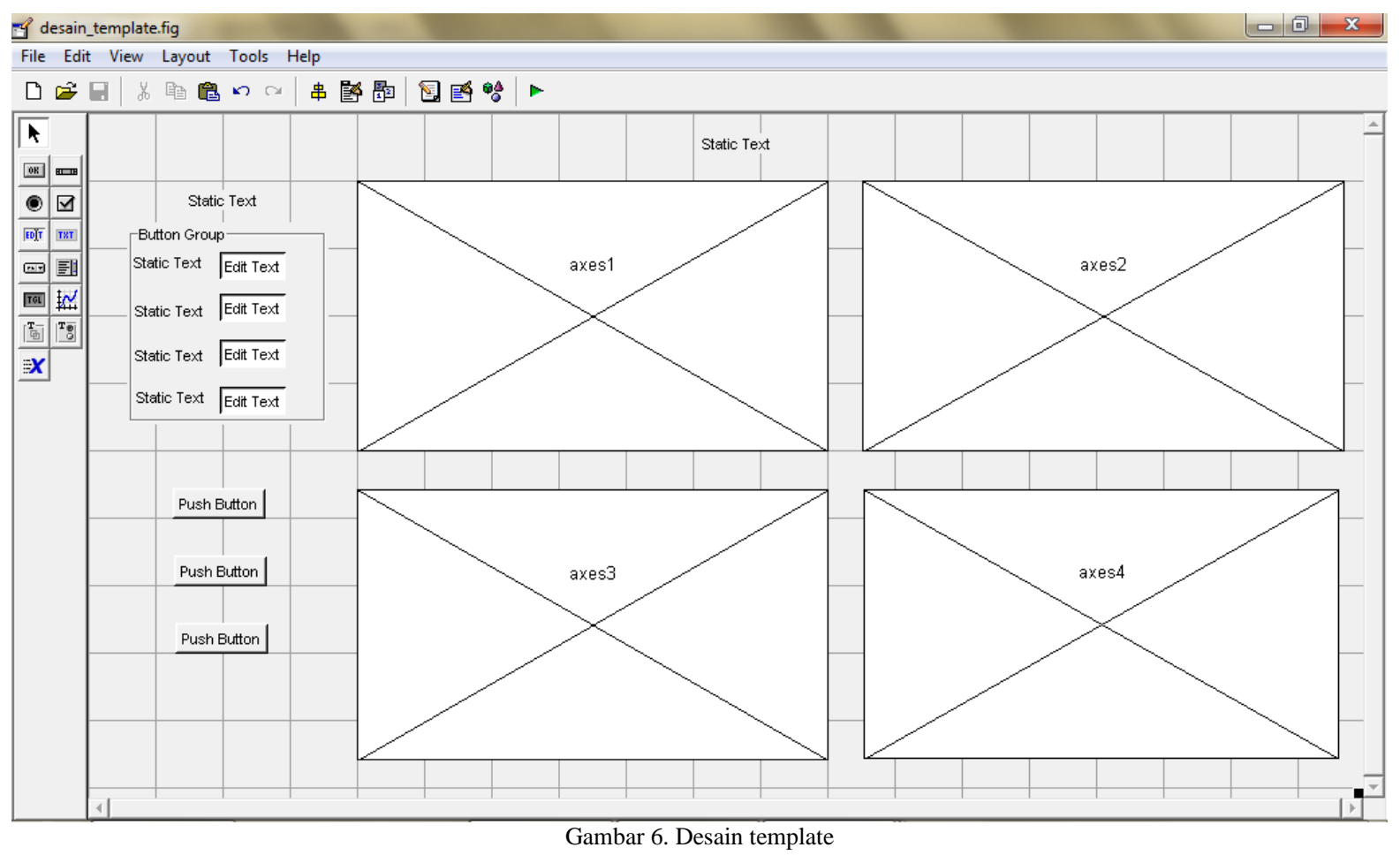


TABEL 1

PROPERTY KOMPONEN UICONTROL

\begin{tabular}{l|l|l}
\hline \multicolumn{1}{c|}{ Komponen } & \multicolumn{1}{|c}{ Tag } & \multicolumn{1}{c}{ String/Title/Name } \\
\hline Static Text 1 & judul & Simulasi Sinyal AM \\
Static Text 2 & amplitudo_informasi & Amplitudo Sinyal Informasi (V) : \\
Static Text 3 & frekuensi_informasi & Frekuensis Sinyal Informasi (Hz) : \\
Static Text 4 & amplitudo_carrier & Amplitudo Sinyal Carrier (V) : \\
Static Text 5 & frekuensi_carrier & Frekuensi Sinyal Carrier (Hz) : \\
Static Text 6 & phase & Phase Sinyal Carrier (derajat) : \\
Button Group 1 & uipanel1 & Parameter Sinyal \\
Edit Text 1 & edit1 & \multicolumn{1}{c}{ - (kosongkan) } \\
Edit Text 2 & edit2 & - (kosongkan) \\
Edit Text 3 & edit3 & - (kosongkan) \\
Edit Text 4 & edit4 & - (kosongkan) \\
Edit Text 5 & edit5 & Buat Grafik \\
Push button 1 & pushbutton1 & Keluar \\
Push button 2 & pushbutton2 & Edit Grafik \\
Push button 3 & pushbutton3 & \\
Axes 1 & axes 1 & \\
Axes 2 & axes 2 & \\
Axes 3 & axes 3 & \\
Axes 4 & axes 4 & \\
\hline
\end{tabular}

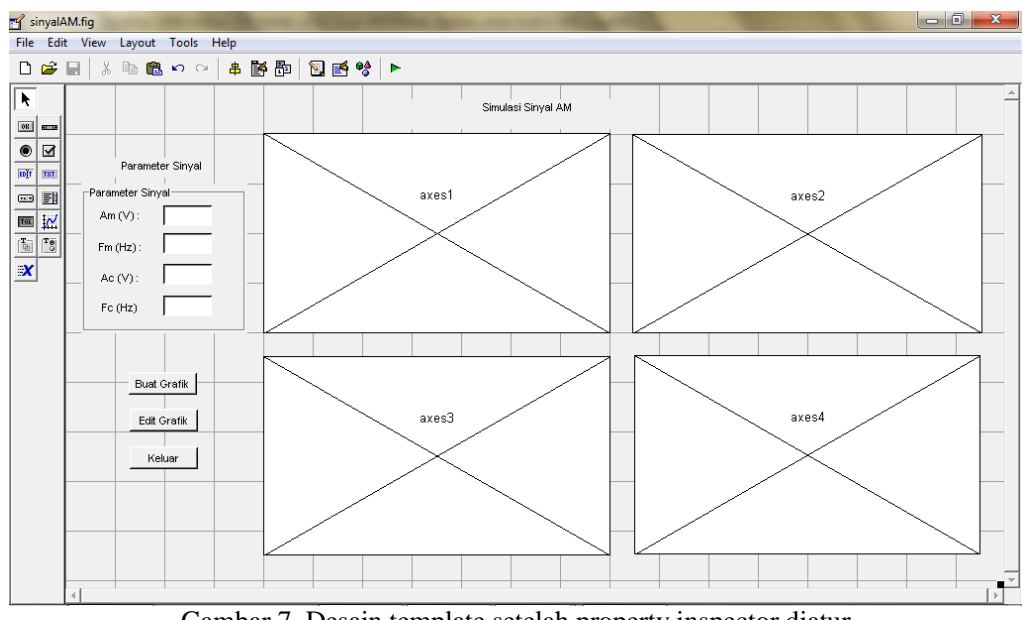

Gambar 7. Desain template setelah property inspector diatur

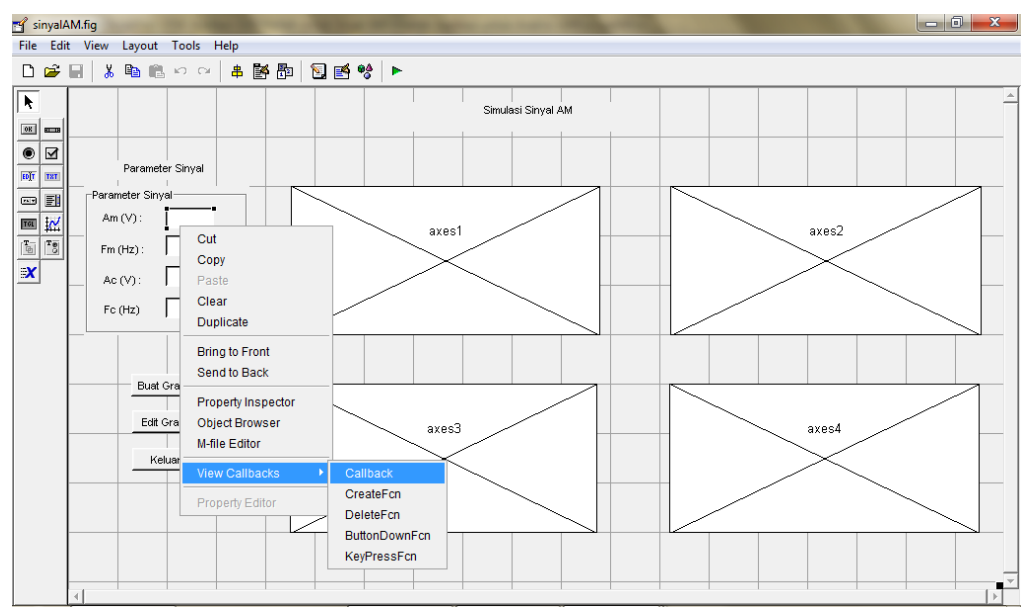

Gambar 8. Menu Callback untuk menampilkan jendela M-File tempat mengetikkan listing program yang dibuat

\section{Membuat Listing Program Matlab}

Listing program dibuat pada Matlab M-File yang bersesuaian dengan Matlab Figure File. Bisa juga dengan menggunakan menu View Callback $\rightarrow$ Callback pada setiap komponen UIControl (gambar 8)[1][4]. 


\section{Pengujian}

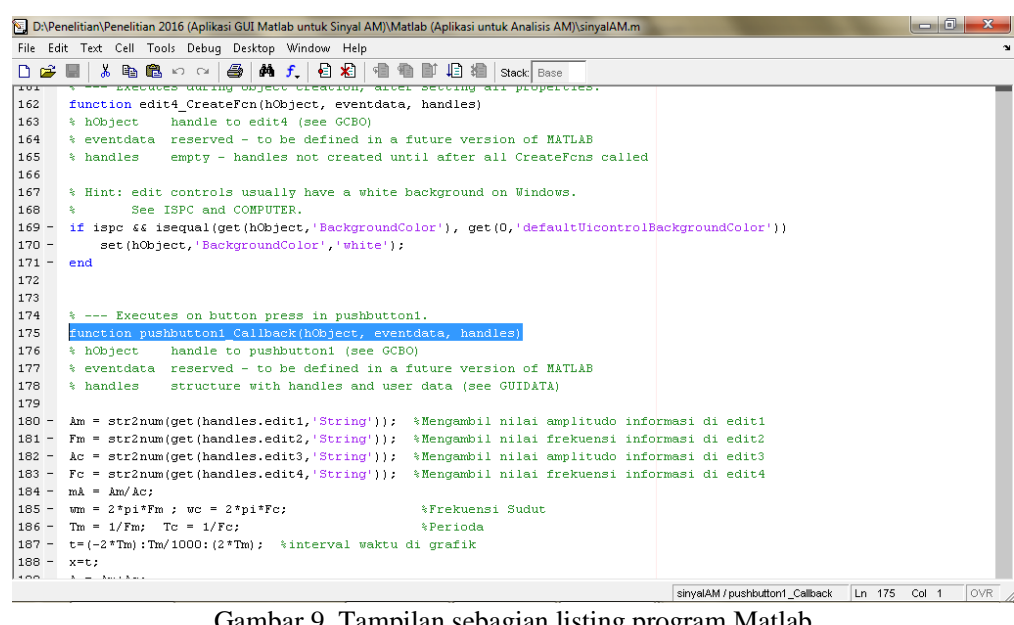

Hasil desain template figure GUI Matlab yang telah dibuat listing programnya, disimulasikan dengan memasukkan nilai parameter amplitudo sinyal yang berbeda untuk menghasilkan nilai indeks modulasi yang bervariasi untuk selanjutnya dianalisis. Frekuensi informasi sebesar $250 \mathrm{~Hz}$ dan $500 \mathrm{~Hz}$ dengan nilai frekuensi carrier $1,5 \mathrm{kHz}$. Sinyal warna merah adalah sinyal informasi yang berasal dari sumber sinyal audio, sinyal warna biru adalah sinyal carrier yang berasal dari oscillator pemancar AM.

Selanjutnya dibuat program untuk simulasi spektrum frekuensi sinyal AM dimana grafik merupakan representasi amplitudo terhadap kawasan frekuensi sinyal. Persamaan spektrum dibuat dengan Transformasi Fourier.

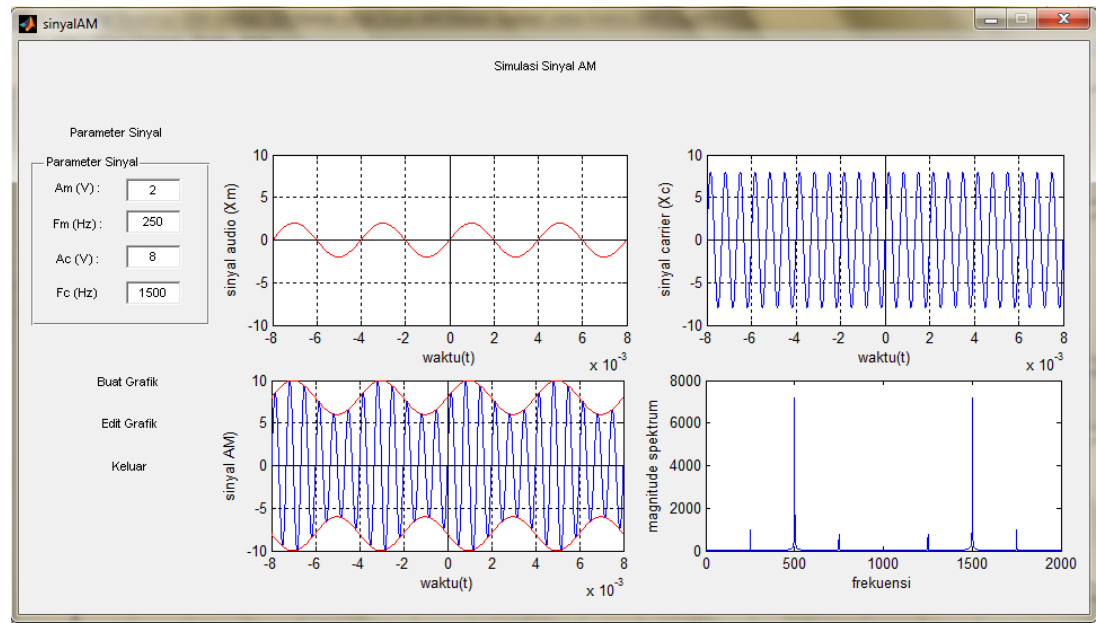

Gambar 10. $\mathrm{Am}=2, \mathrm{Fm}=250 \mathrm{~Hz}, \mathrm{Ac}=8, \mathrm{Fc}=1.5 \mathrm{kHz}, \mathrm{mA}=0.25(\mathrm{~mA} \leq 1$ dan $\mathrm{Fm}<\mathrm{Fc})$

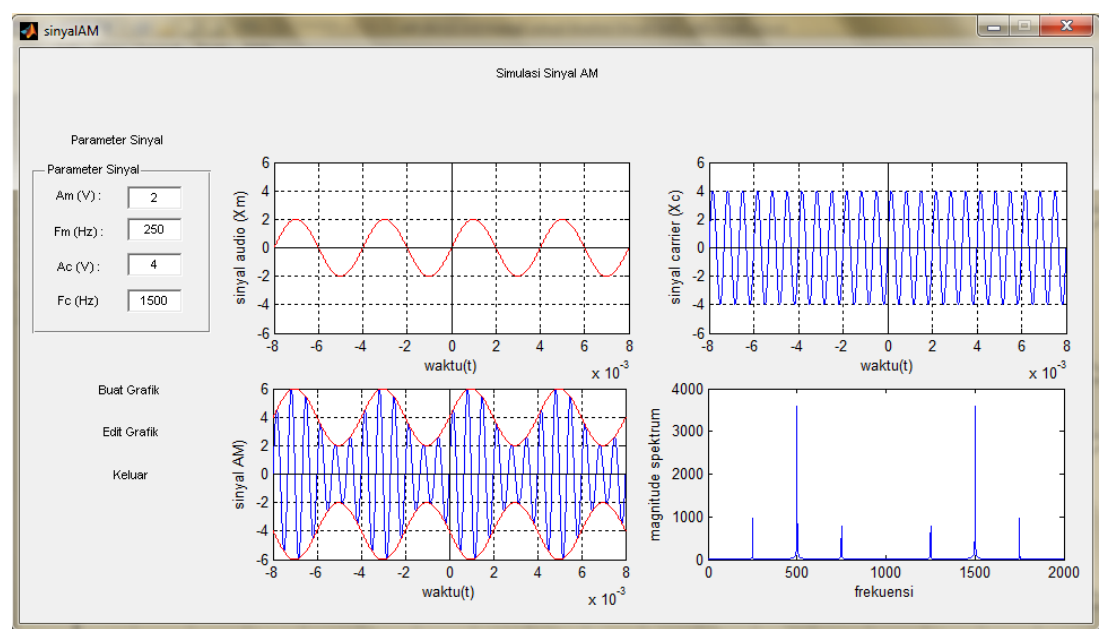

Gambar 11. $\mathrm{Am}=2, \mathrm{Fm}=250 \mathrm{~Hz}, \mathrm{Ac}=4, \mathrm{Fc}=1.5 \mathrm{kHz}, \mathrm{mA}=0.5(\mathrm{~mA} \leq 1$ dan $\mathrm{Fm}<\mathrm{Fc})$ 


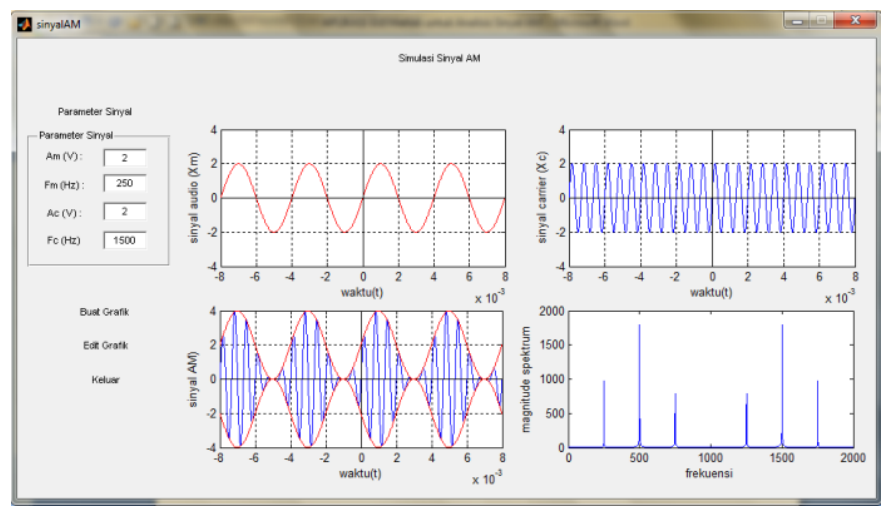

Gambar 12. $\mathrm{Am}=2, \mathrm{Fm}=250 \mathrm{~Hz}, \mathrm{Ac}=2, \mathrm{Fc}=1.5 \mathrm{kHz}, \mathrm{mA}=1(\mathrm{Fm}<\mathrm{Fc})$

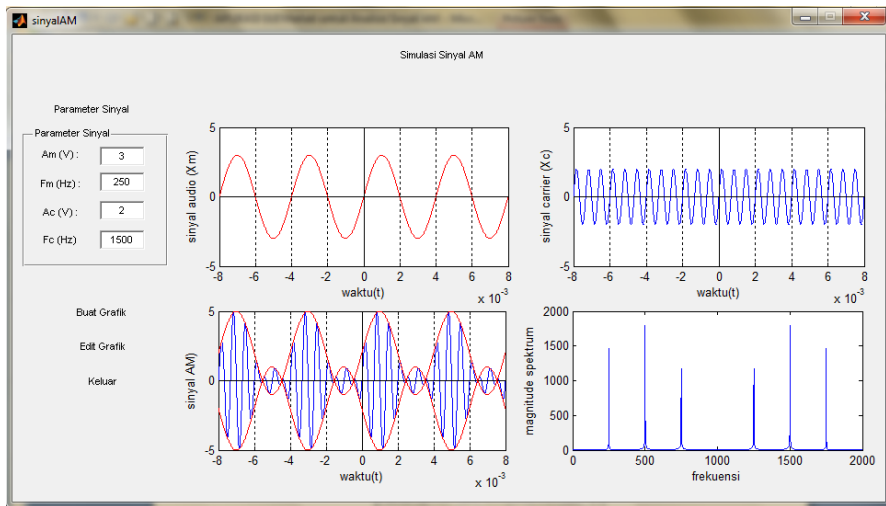

Gambar 13. $\mathrm{Am}=3, \mathrm{Fm}=250 \mathrm{~Hz}, \mathrm{Ac}=2, \mathrm{Fc}=1.5 \mathrm{kHz}, \mathrm{mA}=1.5(\mathrm{~mA}>1)$

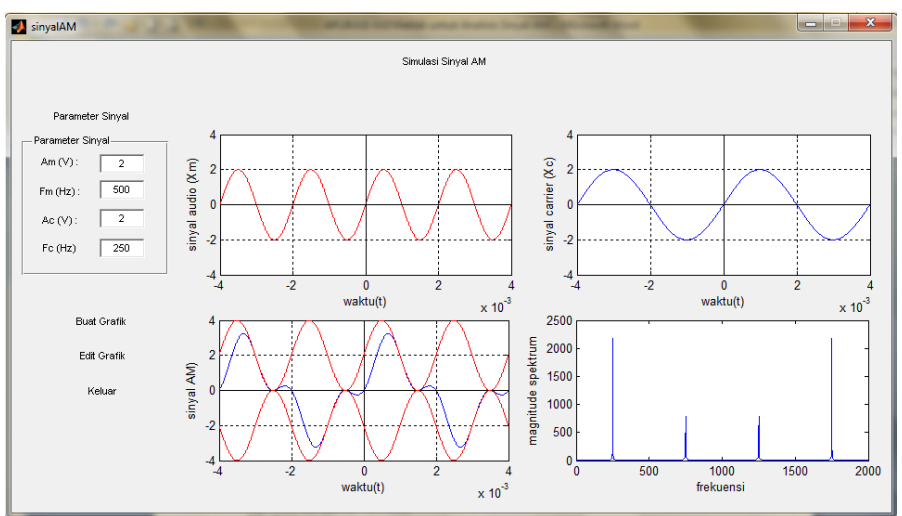

Gambar 14. $\mathrm{Am}=2, \mathrm{Fm}=500 \mathrm{~Hz}, \mathrm{Ac}=2, \mathrm{Fc}=250 \mathrm{~Hz}, \mathrm{~mA}=1(\mathrm{~mA}=1$ dan $\mathrm{Fm}>\mathrm{Fc})$

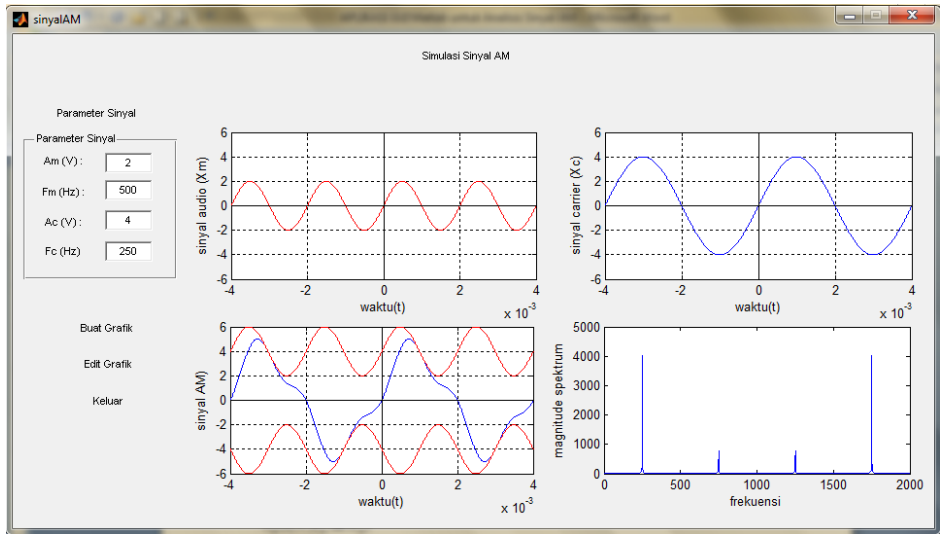

Gambar 15. $\mathrm{Am}=2, \mathrm{Fm}=500 \mathrm{~Hz}, \mathrm{Ac}=4, \mathrm{Fc}=250 \mathrm{~Hz}, \mathrm{~mA}=1(\mathrm{~mA} \leq 1 \mathrm{dan} \mathrm{Fm}>\mathrm{Fc})$ 
E. Analisis Perbandingan

Analisis data untuk gambar 10 dimana $\mathrm{A}_{\mathrm{m}}=2, \mathrm{~F}_{\mathrm{m}}=250 \mathrm{~Hz}, \mathrm{~A}_{\mathrm{c}}=8, \mathrm{~F}_{\mathrm{c}}=1.5 \mathrm{kHz}, \mathrm{m}_{\mathrm{A}}=0.25$, sebagai berikut:

$$
\begin{aligned}
& x_{M}(t)=A_{M} \sin \omega_{M} t \\
& x_{A M}(t)=A_{C}\left(1+m_{A} \cdot \sin \omega_{M} t\right) \sin \omega_{C} t
\end{aligned}
$$

$x_{M}(t)$ maksimum pada saat $\omega_{\mathrm{M}} \mathrm{t}=1 / 2 \pi, t=1$ ms sehingga $x_{\mathrm{AM}}(t)$ maksimum:

$$
x_{A M}(t)=A_{C}(1+0.25)=10 \mathrm{~V}
$$

Kawasan frekuensi spektrum sinyal AM:

$$
\begin{aligned}
& \mathrm{F}_{\mathrm{m}}=250 \mathrm{~Hz} \text { dan } \mathrm{F}_{\mathrm{c}}=1.5 \mathrm{kHz} \\
& \mathrm{F}_{\mathrm{c}}-\mathrm{F}_{\mathrm{m}}=1250 \mathrm{~Hz} \\
& \mathrm{~F}_{\mathrm{c}}+\mathrm{F}_{\mathrm{m}}=1750 \mathrm{~Hz}
\end{aligned}
$$

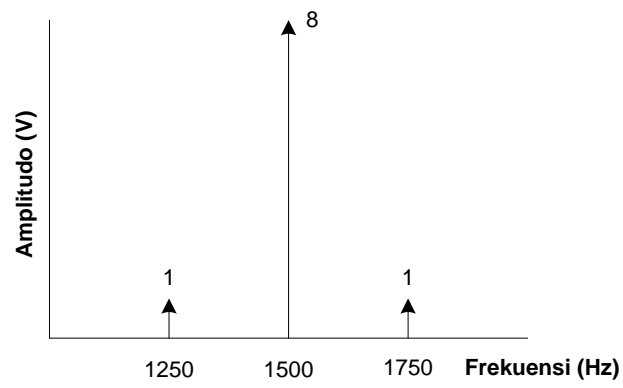

Gambar 16. Sketsa spektrum untuk analisis gambar 10

Pada gambar 10, magnitude spektrum frekuensi $1500 \mathrm{~Hz}$ besarnya 8 kali magnitude spektrum frekuensi $1250 \mathrm{~Hz}$ dan $1750 \mathrm{~Hz}$.

\section{KESIMPULAN}

1. Hasil analisis GUI Matlab yang sesuai dengan karakteristik sinyal AM ditunjukkan pada gambar 10,11 dan 12 .

2. Untuk $m_{\mathrm{A}}>1$, puncak-puncak sinyal pembawa dari sinyal selubung terpotong. Keadaan ini harus dicegah, karena akan menimbulkan cacat pada sinyal modulasi (gambar 13).

3. Batas-batas nilai $m_{\mathrm{A}}$ yang ideal adalah : $0 \leq m_{\mathrm{A}} \leq 1$ (gambar 10, 11 dan 12).

4. Frekuensi sinyal pembawa harus lebih tinggi daripada sinyal informasi. Selain memang untuk memenuhi tujuan modulasi itu sendiri, yakni mengatasi dimensi antenna.

5. Apabila frekuensi sinyal pembawa lebih kecil daripada frekuensi sinyal informasi, maka karakteristik sinyal informasi yang dibawa oleh sinyal pembawa akan hilang sehingga informasi tidak akan sampai ke tujuan (gambar 14 dan 15).

\section{DAFTAR PUSTAKA}

[1] Anggoro Adi Sucipto dan Bambang Suprianto, 2016. Pengembangan Media Pembelajaran Menggunakan GUI Matlab pada Pokok Bahasan Modulasi Analog dan Digital Kelas XI TAV SMK Negeri 1 Sidoarjo. Jurnal Pendidikan Teknik Elektro.Vol 5, No 2. Surabaya.

[2] Budi Setiyanto. 2010. Dasar-dasar Telekomunikasi. Sakti. Yogyakarta.

[3] Dennis Roddy dan John Coolen. 2005. Komunikasi Elektronika. Penerbit Erlangga. Jakarta.

[4] Dwi Aryanta, Arsyad Ramadhan Darlis, Wirda Sri Farhani. 2014. Simulasi Sinkronisasi Carrier Pada Modulasi Digital Menggunakan Matlab. Jurnal Elkomika No.2 Vol. 2. Institut Teknologi Nasional Bandung.

[5] Khairunnisa. 2015. Diktat Mata Kuliah Teknik Telekomunikasi 1. Politeknik Negeri Banjarmasin.

[6] Putri Alit Widyastuti Santiary. 2009. Sistem Verifikasi Modul Modulasi FM (Frekuensi Modulasi) Menggunakan Bahasa Pemrograman Matlab. Jurnal Teknologi Elektro Vol 8, No 2. Universitas Udayana. 